\title{
Spatial aspects of planning logistical centres: The case of the economic centre Feniks in the Posavje Region
}

Spatial planning of logistics centres follows specific spatial and infrastructural requirements, conditioned by desired traffic flux and scope. Spatial and environmental limitations of the usual freight handling sites are forcing logistical activities to search for areas that can ensure undisturbed expansion and practically unlimited traffic flows. The consequence of this trend is suburbanisation coupled with all the spatial and environmental effects. Within this framework, set against the awareness of the uniqueness of any particular site, the article points out the significance of a comprehensive and timely spatial and environmental planning of logistical centres. Therefore clear spatial objectives, transparent analytical starting blocks and adequate planning regulation prove to be the imperative in the spatial planning of logistical centres and formulation of the spatial concept. Simultaneously, and with respect to the complexity of spatial developments, the significance of territorial cohesion is emphasised, which is manifested as territorial identity, territorial quality and territorial efficiency.

Key words: spatial planning, logistical centre, territorial cohesion, spatial regulation, economic centre Feniks in Posavje 


\section{Introduction}

Linkages to transport corridors, nodes of various transport systems, networks of centres as well as freight sources and targets are undoubtedly those starting blocks, which decisively influence the placement of logistical centres. All the above are the self-referential basis upon which practise can responsibly manage, and are therefore not the subject of this article. It does however tackle the spatial planning dimension, which is despite the fast development of activities that promote the blossoming of logistics are nevertheless undernourished. Even on a European scale, the planning of logistical centres and the management of freight transport flows normally falls into the domain of any investors involved and their economic interests. Comprehensive development strategies and spatial planning instruments thus simply follow their desires, instead of constructively managing and directing spatial development.

This article focuses on spatial planning procedures and specific aspects of placing development areas, which are often granted insufficient attention or are brought into the planning process at too late a stage. The article emerges from experiences gained from the preparation of the National spatial plan for the economic centre Feniks in the Posavje region, which was initiated by the Ministry of the economy, commissioned by the Public agency of the Republic of Slovenia for entrepreneurship and foreign investments and prepared by the company LUZ, d.d.

The preparation of the national spatial plan is based on theoretical starting points with regard to comprehensive planning. Being aware of the deficiencies of classical complex planning which lead to the development of other types of planning (Campbell and Fainstein, 1998) and with respect to issues emerging from recent preparations of national planning acts (Zavodnik Lamovšek et al., 2008; Mlakar, 2006), as well as the present European territorial cohesion doctrine (Free University of Brussels - IGEAT, 2006), the methodological framework of the project was set up, which was adapted to meet the specifics of the spatial planning issue at hand. Within the scope of the framework, special emphasis was given to environmental safeguards as a dynamic process, which should be in both methodology and content incessantly, at various levels, with varying accuracy and also different yet linked procedures that would be integrated with spatial planning procedures. Such linkages have in other countries been defined as environmental planning. The estimate of sustainability for national development projects (Plut, 2007) concerning the economy, which should be the first priority in Slovenia, stresses that mastering the environmental pressures of the proposed projects can be met only by adequate micro-location and sustainable layouts of the specified areas, one of which is the economic centre Feniks in Posavje project.
Despite the specifics of the described economic centre, the starting blocks can also be viewed as guidelines for the placement, planning, regulation and management of other economic and logistical centres on a regional level. Simultaneously, the article strives to establish an in-depth scientific debate with regard to improving the presented procedures and a contribution for improvements within the legal framework for the preparation of planning documents for such spatial developments.

\section{Development of the network of logistical centres}

During the last few decades, the spatial organisation of economic activities has been changing in the light of structural changes, new technologies and globalisation trends. Following the industrial revolution, the exchange of goods and the ever constant economic activity have increased and lately reached global dimensions. In general, industrialisation and the corresponding geography of production developed according to the improvements in accessibility, at first conditioned by maritime access and later continental rivers and railways, which connected to roads used for transporting freight (Hesse, 2008).

Today the development of information and communication technologies is the leading factor in the evolution of economic development and connected to the physical distribution of goods. Its consequence is the incorrect representation of logistical activities as virtual flows, which don't experience any physical response in real space. Therefore, the spatial dynamics of freight flow is neglected, as well as their essential effect upon urban development and the concept of land use both on a local and a regional level.

The volume and fluidity of traffic in conjunction with the spatial and urbanisation limitations, force spatially "greedy" land users to find other sites, i.e. locations that allow for expansive growth, unhindered transport flows and are available at a low cost. Such a definition from an operational capability standpoint offers suburban space as the most appropriate solution. Suburbanisation and regionalised logistical activities are however leading to spatial and above all programme changes. The concept of a city, as the centre of trade and exchange of goods is being redefined. Moreover, it is physically manifested in the concepts of land use and the dispersion of the city structure as well as the landscape itself. Developments outside settled areas therefore demand clearly defined planning concepts and future management (regulation) of such areas.

\section{Goal definitions}

The necessity to devise clear goals and spatial concepts, as well as harmonised spatial solutions stems from the hypothesis that 
spatial planning as an activity is one which establishes order and certainty. After analyses, the goals of spatial development have to be clearly reflected in the spatial concept of the planned logistical centre, which should respond to spatial planning issues, such as:

- How do logistical centres integrate into wider development concepts (municipality, regional, state)?

- To which activities does the development of logistical centres refer to, which activities connected to logistical centres will actually develop, what are the spatial and environmental consequences of such parallel developments?

- How will the development of logistical centres affect settlement development and other activities within a given space?

- How will the construction of the logistical centre affect transit and local traffic flows, what are the necessary adaptations to be made to the transport network?

- What environmental effects will be caused by the logistical centre, how will they be alleviated?

- What will be resolved, other than those stated which real issues: issues that hinder the achievement of goals or possible issues that may emerge from the new spatial condition?

Therefore, spatial goals apply to all aspects of thoughts with regard to spatial futures, but also all levels of spatial planning, from the strategic level to the implementation level of particular developments, i.e. the smallest spatially complete units. The fact remains that the planning of logistical centres cannot emerge from data on transport and freight flows alone. It has to grow from the estimates with respect to the role of logistics as an activity and the expected as well as the desired volume of freight traffic in a particular urban or regional environment (Hesse, 2008). From this perspective of functional and spatial logic of freight flow networks and connected possible locations, logistical centres can be conceptualised. Such rationale is the backbone for grafting investor's demands and expectations and the expected effects on a certain environment, if such a development would come to fruition. Hence, the specifics of a particular location are brought into the planning of such centres. In later phases and based on comparative studies, the gradual passage to selection of the best location is possible, whereby the risks for investors are minimised.

Recently territorial cohesion is increasingly emphasised as the vehicle for defining goals and can be sensibly applied to the planning of logistical centres, viewed as complex spatial arrangements, since connectivity is an inherent feature as well as a characteristic of multi-faceted spatial and social influences. Territorial cohesion can be dealt with as the spatial dimension of sustainable development, which mutually interlinks the economic, social and environmental aspects (Free University of Brussels - IGEAT, 2006). The territorial dimension is also directly linked to the competitiveness of the logistical centre, which can be expressed as (Free University of Brussels - IGEAT, 2006; Zavodnik Lamovšek et al., 2008):

- Territorial identity, which in most cases determines development since it defines the capacities of the local production system;

- Territorial quality, which can be defined as a triad with respect to visual attraction, functionality and living quality; and

- Territorial efficiency, which represents the relationship between the effects and the costs, with categories that are not exclusively defined on an economic stepping.

\section{Analyses}

Emphasising the importance of prior analyses is probably unnecessary, but practise shows that the often declarative determination of locations proves that this is not the obvious first step in spatial planning. Planning analyses can be defined as a set of answers to issues linked to the achievement of spatial developments and the resolution of these issues. The key issue that has to be resolved in the planning of logistical centres is the search for a suitable place. Here we confront negotiations between the development and safeguarding issues that may occur.

The key safeguarding measure is the optimisation of the development's site, as the adequate placement of activities can as a rule diminish any effects on the environment. As one of the most successful methods in protective planning we have to (again) point toward the analysis of vulnerability and the establishment of spatial sensitivity, which is a method (mechanism, task, procedure) used to establish by evaluation of the potential influences of the logistical centre on specific spatial components, which sections of the space are more vulnerable or delicate, but above all determine which areas are least suitable for the planned development. Vulnerability therefore doesn't determine the position of the planned logistical centre. To define the possible placement of the logistical centre, space also has to be evaluated according to spatial attraction aspects. This analysis ascertains areas, where the functioning of the logistical centre would be technologically and economically optimised. Besides the criteria for accessibility and any possible future expansion, one of the key factors in the selection of the most suitable site for the economic centre is also the distribution of the projected employment figures and the work force (Nared, 2007).

Confrontation of both aspects within the framework of analysis of spatial suitability discloses possible (alternative) locations, which allow for the achievement of goals in the development of logistical activities and are simultaneously environmentally acceptable. 


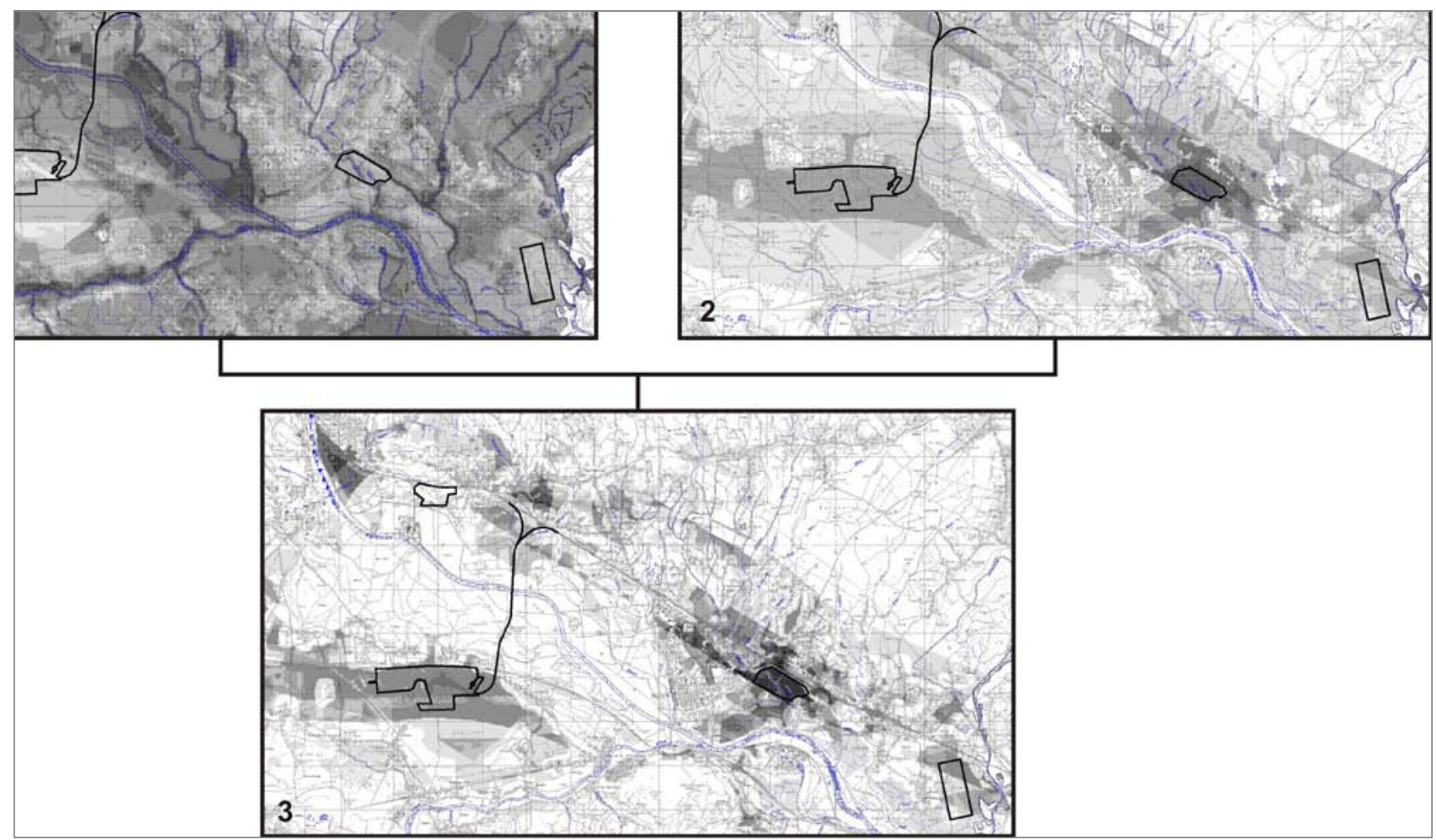

Figure 1: 1 - Analysis of vulnerability (dark - more vulnerable); 2 - Analysis of attraction (dark - more attractive); 3 - Analysis of spatial suitability (dark - more suitable) for the logistical centre within the framework of the economic centre Feniks in Posavje, with marked alternative locations of the centre (source: Mlakar, 2008).

\section{Creation and comparison of alternatives}

The first condition for optimising the decision-making processes is the production of alternatives and allowing for the possibilities for choosing between them (Chechile and Carlisle, 1991). The essence of decision-making is a choice between alternatives, whether in spatial planning, environmental protection, safeguarding cultural heritage, economy or ultimately decision-making on day-to-day life. The successful assessment of the acceptability of spatial developments depends decisively upon the solutions being presented as alternatives (variations, modifications, possibilities, scenarios etc.). In regard to spatial matters, various different, even contradictory interests appear (development, safeguards, partial interests of different groups of spatial users ...), but the project bearer probably has several alternative solutions for achieving one's goal at hand, whereby they all carry differing economic and technical complexities, environmental influences or social acceptability. In the process of determining and also the analyses of alternative decisions, can be taken about how these interests can be respected and which alternative bests suits the defined goals.

The issue of alternatives ties into one of the basic hypotheses of successful environmental (protection) activities, within the scope of spatial planning, which is by safeguarding demands with respect to the assessments of environmental effects, can be enforced only after selecting the alternative, which is environmentally least damaging (Marušič, 1993).

Alternative developments imply differing possibilities for achieving basically the same intended development. In the case of the logistical centre, this means different locations and/or different urbanisation or technological solutions need to be found. Alternatives to development inherently imply different possibilities for achieving the final goal. In the case of the logistical centre, these alternatives can imply different types of freight distribution. Alternatives to developments are therefore alternative strategies and also a part of early planning levels.

Alternative logistical centres can be differentiated into:

- Alternatives concerning differing developments (intent, programme) which refer to the question, "what" to place in a certain area, in conjunction with the development of logistical centres,

- Alternatives concerning different locations for the same development, which refer to the question, "where" to position the planned logistical centre,

- Alternatives concerning the different solutions for the same development, which refer to the question, "how" to position the planned development on the selected site,

- Alternatives concerning the differences in the scope of the development, which refer to the question, "how much" of the available area should actually be utilised. 


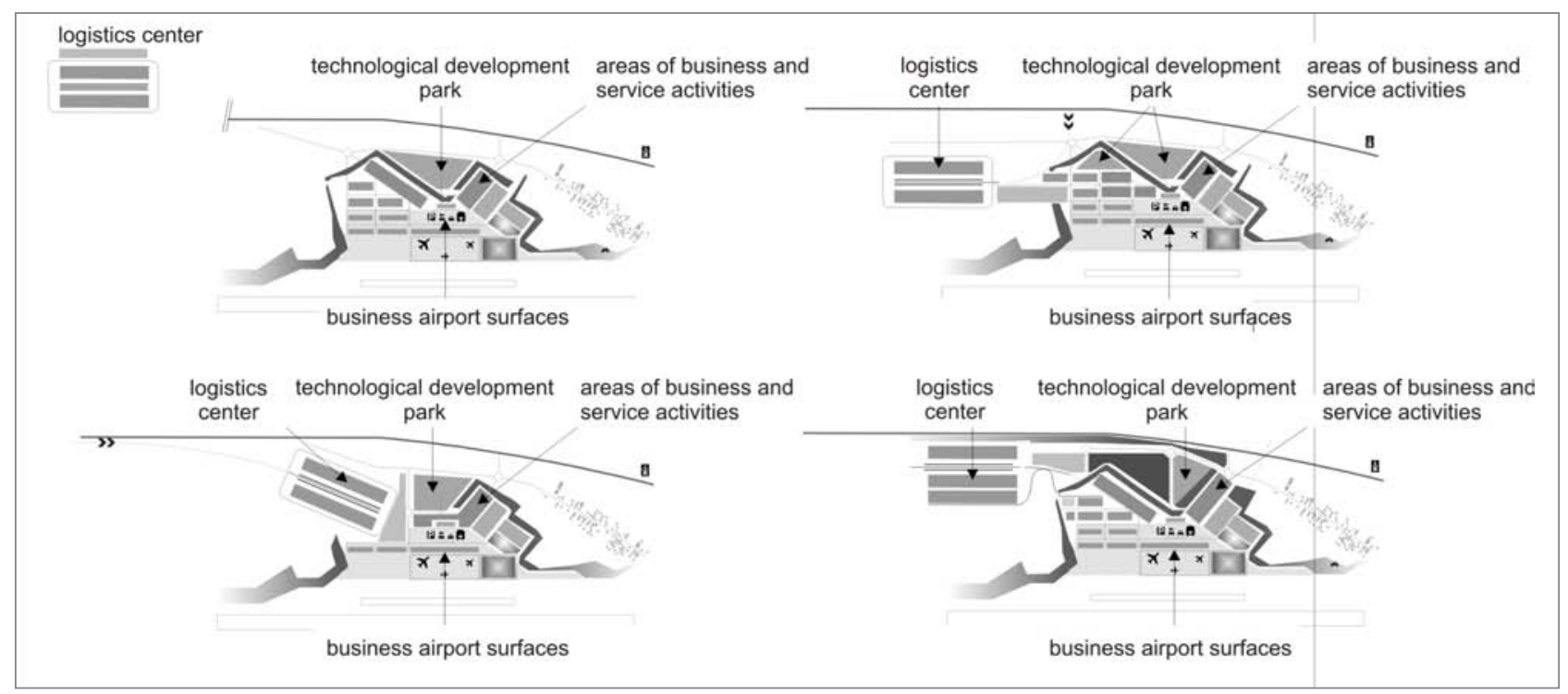

Figure 2: Alternative urbanisation and transport solutions for the central part of the economic centre Feniks in Posavje (source: Mlakar, 2008).

In comparisons of alternative logistical centres, as a rule present planning practises focus on comparisons with four basic aspects:

- Environmental aspect, which corresponds with the preparation of an environmental report regarding a comprehensive environmental impact assessment;

- Spatial aspect the aspect of compliance with regional and urban development;

- Construction-technical aspect the aspect of the functionality of logistical activities;

- Economic aspect, the framework for establishing the investment value and its economic viability.

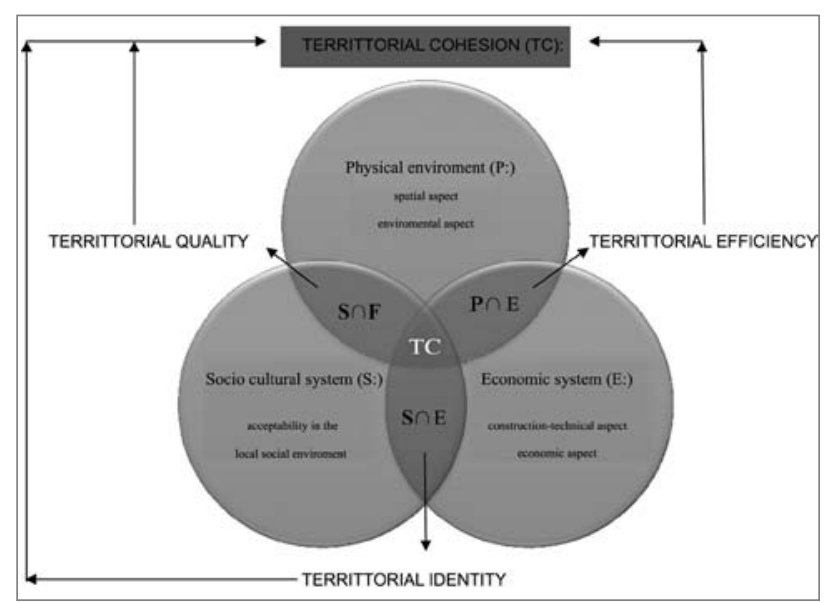

Figure 3: The distribution of five aspects of assessment in the study of variations following Venn's diagram on spatial cohesion (source: Zavodnik Lamovšek, 2008; adapted from Free University of Brussels - IGEAT, 2006, and Radej, 2008).

Simultaneously in the spatial planning procedure, acceptability in the (local, wider) social environment is also established. This is basically an established process, so we will not delve into it any further. We nevertheless have to point out the necessary reform of the procedure, with respect to the clearer definition of goals and establishment, as well as the achievement of territorial cohesion, emphasised in the introduction (Zavodnik Lamovšek et al., 2008).

\section{Devising the concept}

The shift in awareness about specific and truly unrepeatable properties of particular locations implies a new platform in the development of the planning of logistical centres. The design of the conceptual solution with the correct internal organisation and linkages to the wider space is based on correct economic forecasts, knowledge about the spatial characteristics of the area and the proposed programme. For the planner, knowledge about the preset programme is of key importance. The defining of the programme should ensure an adequate response to almost all known spatial issues, enable correct zoning, routing of the traffic network and the correct layout of the utilities infrastructure, but also diminish any possible errors in the regulating of particular zones. The conceptual solution has to be oriented towards the built but also the un-built contexts and resolve the internal organisation of the centre. The established concept gives beforehand directions for zoning and provides the basis for regulating the area using urbanisation parameters.

The primary planning starting points for devising the development concept of logistical centres are:

- Creation of rational road and railway freight routes with possibilities for phased construction;

- Devising a spatial concept, which enables phasing, whereby particular developments are not sequenced; 


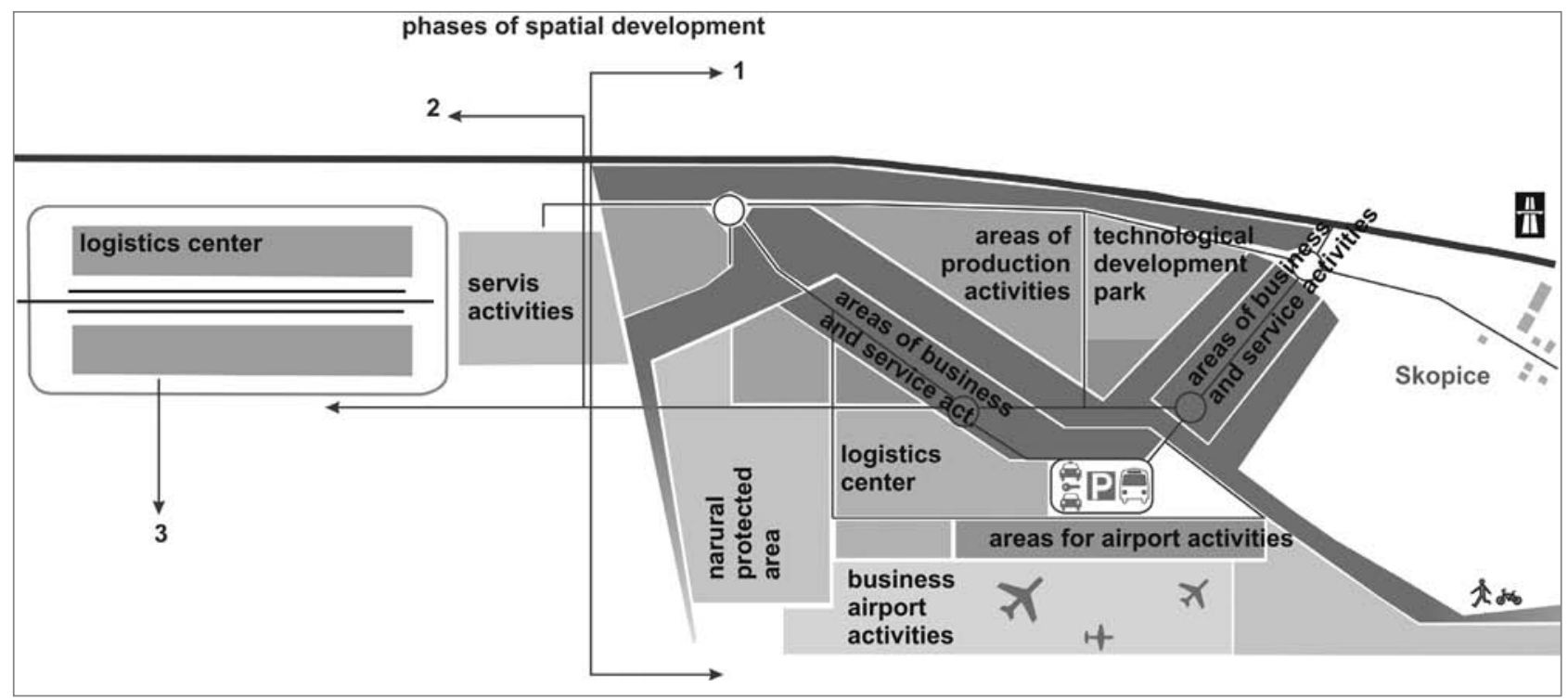

Figure 4: Concept of the economic centre Feniks (source: Mlakar, 2008).

- Programme dividing of the area into several units with complementary and interlinked contents and infrastructures;

- Respect for natural and built characteristics and the limitations of the natural and cultural safeguarding aspects;

- Possible developments on agricultural land have to ensure completeness and uniformity of agricultural land complexes;

- Rational use of energy;

- Respect for measures that limit the influences on the environment;

- The layout of the centre has to follow an already adopted arrangement.

\section{Regulation of logistical centres}

Logistical centres are typical examples of materialised economic surges and the responsiveness of planning proposals to suit market demands. The pursuit of such principles demands flexible regulation, which can correctly direct spatial development with a minimal set of parameters. Here the following have to be defined:

- Land use concept and structuring into areas of functionally compatible uses with conditions for architectural and landscape-architectural design,

- Transport networks,

- Utilities.

Open systems provide better adaptability opportunities. The quantity of possible solutions is therefore vast, which is important in cases when planning is not undertaken for a known investor.

\subsection{Structuring into spatial units with conditions for architectural and landscape-architectural design}

Logistical centres are not "mono-functional" areas. Besides the primary activities related to transport, warehousing and distribution, many other complementary activities with "public" or central characteristics are included (customs, offices, post office, bank ...). To avoid the mixing of incompatible activities, the area is subdivided into particular uniform functional and spatial units. The definition of spatial units as the basic building blocks surely represents the simplification of spatial planning methods and regulation, but simultaneously such subdivision leads to the optimal operation of the centre and enhances the synergetic effects of the proposed activities.

The spatial unit is annotated with dedicated land use, permissible activities and buildings and specific maximised acceptable factors of building density, use and building heights. Mixing is allowed in the unit, which is one of the basic principles of modern cities, but nevertheless only within the framework of compatible activities. Internal heterogeneity of permissible activities and buildings is externally unified by design criteria. A spatial unit simultaneously ensures programme heterogeneity, connections of content, infrastructure and uniform morphological structures.

Regulation of the area differs in view of the proposed land use of particular units. To avoid over-regulation (rigidity) of spatial units, a combination of two or three essential factors and planning conditions are most important, i.e. floor space index, building density factor and permissible height levels. If two of the three conditions are defined we already have a fairly 


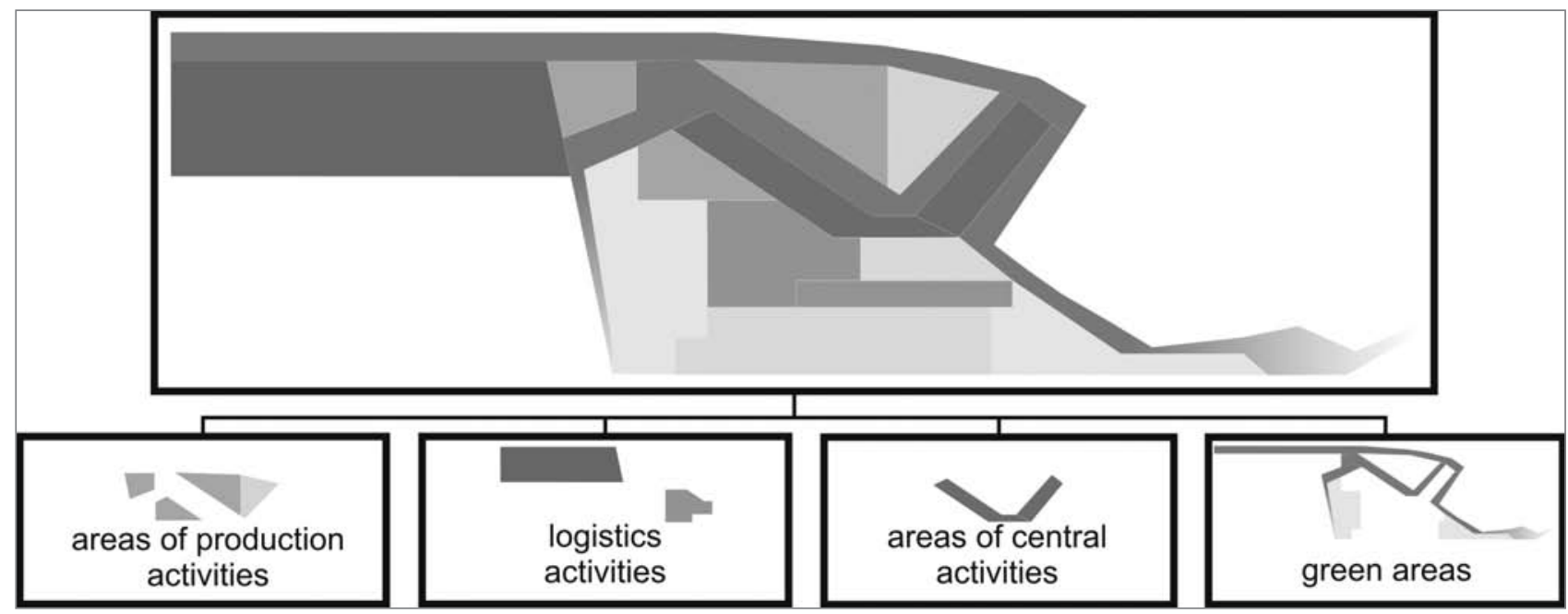

Figure 5: Area of uniform planning in the case of the economic centre Feniks (source: Mlakar, 2008).

precise spatial framework, but simultaneously a fairly expansive space for manoeuvring, thus buildings for different activities and with different typologies can be positioned. Because of the nature of production activities, which generally demands buildings with larger volumes, areas for production and logistical activities are regulated with permissible building density and height levels. The floor space index is generally applied in areas where buildings with standard floors are planned (floor height 2.5-3, 0-3.5 m). Areas of central activities are therefore regulated by a combination of the maximum floor space index and by the number of floors.

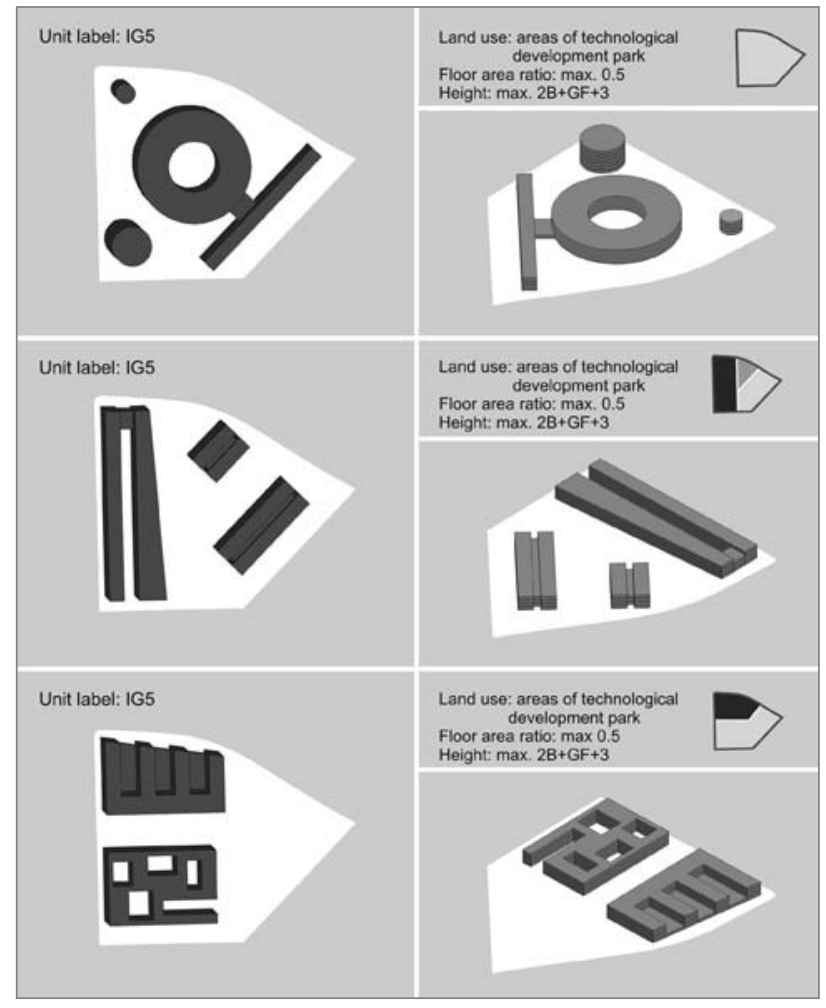

Figure 6: Regulation of the logistical centre and the flexibility of solutions, enabled by such regulations (source: Mlakar, 2008).

\subsection{Definition of the transport network}

Concerning levels of traffic generated by logistical centres, decisions regarding the integration of freight transport flows has a strategic bearing, whereby the expected influences of planned centres have to be integrated and other documents concerning the proposed developments of the transport infrastructure (Hesse, 2004). The significance of a rational transport networks is the basic hypothesis in planning logistical centres. Planned roads have to be driven in a manner that ensures the shortest and fastest links from the entrance to the destination station. It is sensible to plan one or two roads of the highest rank and an orbital road, from which lower ranked roads are lead, i.e. access roads and paths. The classification of roads enables the differentiation of traffic and alleviates noise from freight and transit vehicles. The role and rank of particular roads also determine their regulation measures. Higher ranking roads have to include passageways for pedestrians and cyclists, as well as reserved space for the lining of trees. Within a particular spatial unit further detailing of the roads network is unnecessary, since such arrangements depend on the investor's demands, the number of buildings and ownership structure. Suggested structuring should suffice. So a higher level of flexibility in the merging or subdivision of spatial units is attained.

A modular system, based on the layouts of particular areas, was developed for the Economic Centre Feniks, which is laid out on a grid, measuring $100 \mathrm{~m} / 115 \mathrm{~m}$ on the a/c axis and $75 \mathrm{~m} / 100 \mathrm{~m}$ on the $\mathrm{b} / \mathrm{d}$ axis. The grid was developed from the demand for a rational plot size, terrain configuration and natural features. The structuring indirectly also points to a proposed traffic regime.

The flexible layout allows various possibilities for fragmenting and joining building areas with respect to the stipulated permissible activities and buildings in particular units. These are 


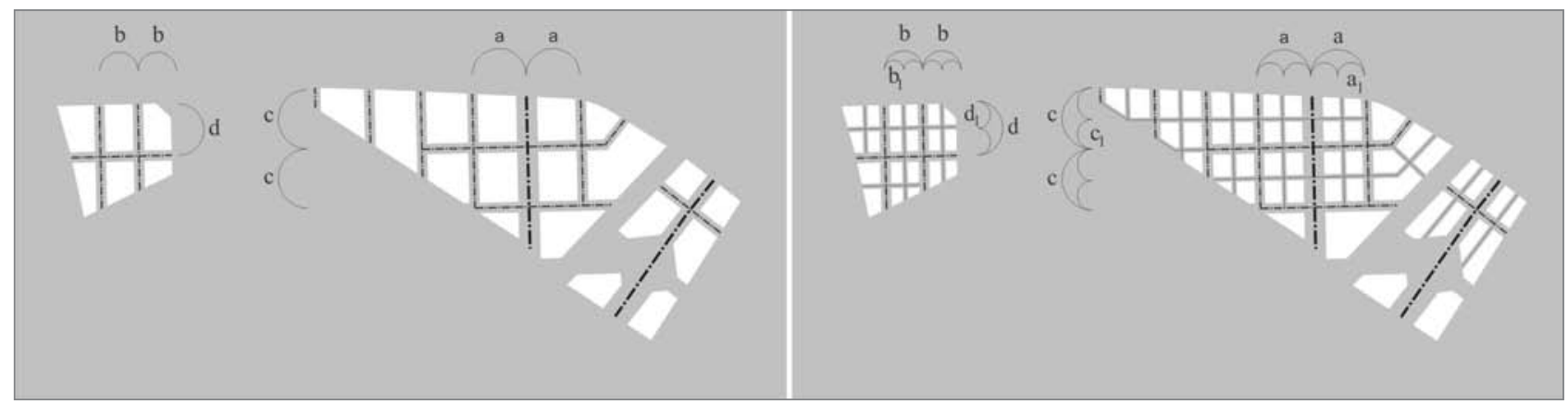

Figure 7: Proposed transport network in the case of the economic centre Feniks (source: Mlakar, 2008).

subdivided into smaller areas, intended for placing the planned buildings and other developments. The units can be joined according to the draft proposals of the layout prepared by independent investors. They are only limited by the regulation lines of the roads, whereby every unit has at least one access and a utilities interface.

\subsection{Definition of the methods and levels regarding the provision of utilities}

From the aspect of utilities provision within the concept, a unified management of the utilities infrastructure is of key importance, since the public nature of infrastructure demands uniformity in planning, operation of all systems and the provision for particular buildings. The complexity of the intertwined activities of the logistical centre demands early planning, with regard to the provision of utilities within the buildings.

Therefore it is necessary to attempt to respond to various questions in the earliest logistical centre during the planning phase, such as:

- How much potable/technological water is needed for particular activities/buildings/areas? How can consumption be reduced? Where is the source that can provide the required quantity and quality located?

- What are the demands concerning fire protection of the buildings and the activities within and what are the available fire fighting possibilities in the wider context?

- What kind of refuse water is generated in the entire area of the logistical centre and what is its quantity?

- Are conduits for refuse water available or does the issue of refuse water gathering and treatment have to be resolved on site?

- What kind of waste is generated on site? Can waste from specific activities generated in the centre be treated on site?

- What are the heating and cooling requirements of particular activities/buildings? What are the expected temperature regimes?

- What materials and building technologies will be applied to reduce energy consumption?

- How much electrical energy will be needed for particular activities/buildings?

- Are there possibilities for using renewable energy sources (the national regulation demands that $25 \%$ of the necessary energy is obtained from renewable sources)?

- What are the managerial and financial consequences of the proposed utilities infrastructure for the logistical centre and its users?

All these questions can be summarised into one: How to plan the utilities infrastructure and ensure the necessary services are available to reduce costs, with the simultaneous suitable and adequate provision, as well as the efficient and lowest use of resources?

\subsubsection{Particular aspects of planning the environmental infrastructure}

Classical methods of planning provisions with potable water generally define the consumption of potable and technical water, in order to the check the capacity of the available extant waterworks network, as well as its capacity. When planning the water provision network, the issue of water for fire fighting has to be addressed. Technological processes in particular activities in the logistical centre (manufacturing, warehousing) can represent a high fire risk. Therefore, the construction of an adequate hydrant system is necessary. If the public waterworks network cannot ensure the necessary quantities of water for fire safety, space has to be dedicated within the logistical centre for a service reservoir and a hydrant system built. Considering the availability of the (potable) water resource and with respect to the desired alleviation of the extant waterworks network, checking the possibility of tapping into the subterranean aquifer on the site itself is a reasonable option. Even the need for technical water can be substantial, therefore the use of closed technological circles is recommended, with the reuse of water and the possible exploitation of groundwater on the site itself, also in combination with the exploitation of water for fire fighting services. 
To reduce the use of potable water in the sense of sustainable development and to reduce the consumption of water, several principles apply here which are mostly tied to responsible usage. An important element in the reduction of consumption is the possible use of so called "grey" water, which is in fact used water that hasn't been contaminated by faeces or similar matter. Grey water can be used in buildings for flushing toilets and watering the centre's green surfaces. Thus, part of the potable water can directly return to the aquifer and alleviate pressure on the sewage system.

The best solution for dealing with refuse water is to connect the local sewage system to the extant one and the refuse water treatment plant in the settlement. If the latter is too far, a small water treatment plant can be installed in the centre itself. Aligned to the principles of sustainability, the construction of biological water treatment plants is recommended, which can be suitably integrated into the system of green and open spaces within the logistical centre.

Due to the dense nature of the buildings in logistical centres, with a high ratio of paved surfaces, implies less precipitation sieving into the aquifer, which increases the burden on the sewage system, rivers and streams and increases the danger of flooding down river. Because of the high drainage coefficients (the share of water that is channelled from the surface to the culvert) we are dealing with large volumes of atmospheric water that has to be drained from these surfaces. To diminish or prolong the drainage of atmospheric water recommendations are in place for dispersed retention of water on the surface (roof gardens), drainage to the aquifer (green surfaces, parking lots with permeable paving surfaces), concentrated retention on the surface (dry or wet reservoirs, which can be used for landscaping or parks), concentrated underground retention (retention basins and canals) and soak away channels (soak away fields, drainage). Modern concepts of urban drainage tend to copy natural processes and the retention or drainage of water on the site itself. One of the consequences of such spatial policy is a wide field for landscape design and the creation of expansive green surfaces in the vicinity of large settlement complexes, which inherently improve the quality of the living and working environments.

\subsubsection{Particular aspects of planning energy infrastructures}

The Resolution on the national energy programme, which is based on the use of renewable energy sources and its efficient use, is the basis for energy provision in Slovenia. The regulation stipulates that for all buildings exceeding $1000 \mathrm{~m}^{2}$ a feasibility study for alternative energy provision systems has to be undertaken (unless the type of energy provision has already been specified in the local energy concept or other regulation). Alternative systems are:

- Distance or remote heating or cooling, if available;

- Heat pumps;

- Decentralised systems based on the use of renewable energy sources;

- Co-production of heating/cooling and electricity.

Based on data concerning needs for the energy for cooling and heating, as well as electrical energy, the study on energy provision determines a suitable provision system. The best provision system for logistical centres is central distance or remote heating, which can also provide cooling, although remote systems are mostly applied in city centres, therefore the realistic possibility of connecting to an extant system is rather slim. Heat pumps can provide only a low temperature heating regime, which is generally less acceptable for the needs of a logistical centre.

The use of de-centralised systems based on renewable energy sources is spatially conditioned. The use of wind generators in logistical centres is fairly difficult due to their size. The use of geo-thermal energy is recommended, especially in areas with a high geo-thermal potential, whereby this resource (similarly to other heat pumps) is more adequate a supply in smaller buildings or areas. The use of wood/bio-mass is suitable mainly in areas, where the central energy unit produces heat, yet it is important to provide suitable surfaces for the production unit and a fuel depository. The typology of buildings that appear at logistical centres is exceptionally beneficial for the installation of photo-voltaic elements and use of solar energy, albeit the initial investment is high, in the life cycle of the installation the produced electrical energy and savings prove substantial in the long run. When using solar energy we have to consider other options, from systems for the passive heating of buildings to the proper construction of facades and walls, as well as solar elements for preparation of warm water.

In the co-production of heating/cooling and electrical energy (co- and three-generation) the primary energy of the fuel is used to its maximum capacity in order to produce the maximum quantities of heat and electrical energy, as well as cooling, with the introduction of absorption coolers. The system proves economical in areas where there are genuinely sufficient needs for heating, cooling and electrical energy. Apparently logistical centres are suitable for installation with such forms of energy provision, since they use energy for heating during the winter, cooling in the summer and preparation of warm sanitary water and electrical energy throughout the year. The main fuel is natural gas. This arrangement requires the installation of a central production unit for heat/cooling/electrical energy, from which the heating and cooling grids branch towards the particular buildings. 


\section{Management}

The planning of logistical centres cannot end with the adoption of a detailed planning document. To ensure a spatially and environmentally acceptable establishment and operation of a logistical centre, it is sensible to provide a comprehensive management and maintenance programme of the economic centre's area, which should include at least:

- Displacement of enterprises with respect to their spatial requirements, proposed activities and expected environmental effects and the rational phasing of territorial development;

- Co-ordination in preparation of project documentation and co-operation in procedures concerning building, utilities provision and environmental protection;

- Evaluation of the suitability of particular project solutions to ensure the design and functional harmonisation of the economic centre and the required provision of utilities and energy infrastructures;

- Assessment of the environmental suitability of particular proposed activities to ensure the prevention of possible excessive influences on the environment and also to ensure adequate working conditions;

- A unified management of registers dealing with property evidences and environmental protection;

- Maintenance of traffic and utility infrastructures and electronic communications;

- Maintenance of open green areas;

- Refuse management;

- Safeguarding that natural and other calamities don't take place;

- Executing and harmonising monitoring;

- Executing and harmonising the implementation of additional protection measures, which are conducted following the monitoring process.

\section{Conclusion}

The spatial and environmental planning of logistical centres doesn't significantly differ from the planning of other spatial arrangements. Successful planning is conditioned upon clearly defined objectives, which have to refer to all aspects of conceptualising the territory's future. The duty of spatial planning in the preparatory phase is to sensibly negotiate the safeguarding and developmental aspects of the project, as well as particular spatial interests and joining them into distinct, efficient and high quality spatial arrangements. Therefore, to ensure the successful assessment of suitability with great harmonisation, it is of key importance that the proposed logistical centre is built on transparent analysis and presented in alternatives. Uncertainty about social acceptability of such developments can be overcome, only if we are aware that other or better possibilities are not available.

Spatial development goals have to be clearly manifested in the spatial concept, which is formalised into the rights and obligations on the specific territory by stipulated regulation elements, concerning spatial management and environmental protection in the adopted planning act (land use, density, measurements, environmental conditions ...). Public participation, which should strive for the establishment of common goals and development oriented solutions, is of key importance.

Jure Zavrtanik, Architect

LUZ, d.d., Ljubljana, Slovenia

E-mail: jure.zavrtanik@luz.si

Dr. Aleš Mlakar, Landscape Architect

University of Ljubljana, Biotechnical Faculty, Department of Lan-

dscape Architecture, Ljubljana, Slovenia

E-mail: ales_mlakar@siol.net

Marko Fatur, Civil Engineer

LUZ, d.d., Ljubljana, Slovenia

E-mail:marko.fatur@luz.si

\section{References}

Bina, O. (2001) Strategic environmental assessment of transport coridors: Lessons learned comparing the methods of five member states. London, European Commission, DG Environment, Environmental Resources Management.

Canadian Environmental Assessment Agency (1996) The Canadian environmental assessment act. Reference guide on physical and cultural heritage resources. Ottawa, Canada.

Campbell, S., and Fainstein, S. S. (1998) Introduction: The structure and debates of planning theory. In: Campbell S., and Fainstein S. S. (eds.) Readings in planning theory, pp. 1-14. Malden, Blackwell Publishers Inc.

Chechile, R. A., and Carlisle, S. (eds.) (1991) Environmental decision making: A multidisciplinary perspective. New York, Van Nostrand Reinhold.

European Commission (2003) Implementation of Directive 2001/42 on the Assessment of the effects of certain plans and programmes on the environment. Luxembourg, Office for Official Publications of the European Communities.

Free University of Brussels - IGEAT (2006) Espon project 3.2. Spatial scenarios and orientations in relation to the ESDP and cohesion polic: Teritorial impact assessment. Final report. Volume 5. Bruxelles.

Gajšek, M. (2000) Prostorsko planiranje in omrežje mest v Sloveniji: Kako prometno-logistični terminali in podjetniške cone spodbujajo razvoj mest. Urbani izziv, 11(1), pp. 27-33.

Hesse, M. (2004) The transport geography of logistics and freight distribution. Journal of Transport Geography, 12(3), pp. 171-184.

Hesse, M. (2008) The city as a terminal: The urban context of logistics and freight transport. Farnham, Ashgate. 
Lyle, J. T. (1985) Design for human ecosystems. New York, Van Nostrand Reinhold.

Marušič, J. (1993) Optimizacijski postopki kot sredstvo za vključevanje varovalnih presoj v celokupno in z okoljem skladno prostorsko načrtovanje. Ljubljana, Katedra za krajinsko arhitekturo, Biotehniška fakulteta.

Mlakar, A. (2006) Možnosti zmanjševanja negotovosti v prostorsko načrtovalnih postopkih. Ph.D. thesis. Ljubljana, Univerza v Ljubljani, Biotehniška fakulteta.

Mlakar, A. (ed.) (2008) Državni prostorski načrt za gospodarsko središče Feniks v Posavju. Dopolnjen osnutek. Ljubljana, LUZ d.d., Ministrstvo za gospodarstvo, Ministrstvo za okolje in prostor, Direktorat za prostor.

Nared, J. (2007) Model razporeditve pričakovanih delovnih mest kot instrument za načrtovanje in vrednotenje projektov: primer Resolucije o nacionalnih razvojnih projektih za obdobje 2007-2023. In: Nared, J., Perko, D., Ravbar, M., Horvat, A., Hren, M., Juvančič, L., et al. (eds.) Regionalni razvoj 1: Veliki razvojni projekti in skladni regionalni razvoj. Ljubljana, Založba ZRC, ZRC SAZU.

Noteboom, S. (1999) Environmental assessments of strategic decisions and project decision: Interactions and benefits. DHV Environment and Infrastructure Publication of the Ministry of Housing, Spatial Planning and the Environment, The Netherlands.

Plut, D. (2007) Sonaravna ocena nacionalnih razvojnih projektov Slovenije (2007-2023). In: Nared, J., Perko, D., Ravbar, M., Horvat, A., Hren, M., Juvančič, L., et al. (eds.) Regionalni razvoj 1: Veliki razvojni projekti in skladni regionalni razvoj. Ljubljana, Založba ZRC, ZRC SAZU.

Radej, B. (2008) Sinteza vplivov nacionalnega energetskega programa na prostorsko kohezijo Slovenije: Delovni zvezek št. 2. Ljubljana, Slovensko društvo evalvatorjev.

Taylor, P. W. (1986) Respect for nature. Princeton, Princeton University Press.

Zavodnik Lamovšek, A., Hudoklin, J., Peterlin, M., and Mlakar, A. (2008) Priprava strokovnih osnov za oblikovanje metodologije vrednotenja in medsebojne primerjave različic $v$ postopkih priprave državnega prostorskega načrta s prostorskega in urbanističnega vidika. Ljubljana, Univerza v Ljubljani, Fakulteta za gradbeništvo in geodezijo, Ministrstvo za okolje in prostor, Direktorat za prostor. 